\title{
Place and role of cultural anthropology in the Military
}

\author{
SZTANKAI Krisztián ${ }^{1}$
}

\begin{abstract}
Action-anthropology is one branch of cultural anthropology that as an interdiscipline can promote the more effective functioning of the system of the Hungarian Defence Force's mission operations planning, training, and task implementation. Cultural anthropology - and the sub-discipline action-anthropology - is a branch of social science utilizing methods of theory and knowledge to solve practical social problems; therefore, it is suitable for special research in mission areas. Keywords: Anthropology, Action anthropology, cooperation, Hungarian Defence Forces (HDF)
\end{abstract}

\section{Cultural Anthropology}

Cultural anthropology is a branch of anthropology. In the UK it is called social anthropology or socio-cultural anthropology. Cultural anthropology researches the culture and social organization of various nations and ethnic groups primarily on empirical basis and upon empirical facts. As the main method of gathering material, participant observation is considered, which distinguishes it from all other sciences that study culture and society. The methods and scientific thesis make anthropology suitable for studying any small, closed community or subculture. Learning about other cultures and the development of cultural sensitivity towards other societies - ethnic, religious, political, etc. — in addition to teaching tolerance, is extremely important to learn both in domestic academic life and in military science and the military missions of the future.

In this current work we do not wish to elaborate the relationship of ethnology, ethnography and cultural anthropology because it is not the subject of this article, but it is worth knowing that folklore is a science that inspects the life of groups who live in a traditional way of life and which are mainly peasant, nomad and gatherer groups. Ethnology deals with the comparison of these phenomena and the discovery of structure and context.

\section{So what exactly is cultural anthropology?}

Definitions: The Dictionary of Foreign Words in 1983, defined anthropology as the science of the human that deals with the natural endowments of the human and his organizational structure. According to the Encyclopaedia of Folk [6: 104] in Hungary the biological sciences include anthropology, and it only refers to the use of economic, cultural and social anthropology. We could learn Ethnography from the Ethnography Encyclopaedia [6: 743] as the internationally recognized and used name for ethnography, which is a part of ethnological

1 k.sztankai@gmail.com 
research. Although from the definition of the Encyclopaedia of Ethnology it is clear that in the British areas the science dealing with cultural and social anthropology is known as a synonym of ethnography. One should not be surprised that a professional anthropologist perceives himself an ethnographer, or an ethnography researcher, this problem is present in anthropology society to this day. One thing is certain, that anthropology is an inter-disciplinary science that utilizes both ethnography and ethnographic methods and experience.

\section{Cultural anthropology in the higher education of Hungary}

The first Hungarian anthropological work titled "Anthropology is the description of humanity” was published by Fejér György in 1807. In 1878 the National Archaeological and Anthropological Society was founded, and the world's fourth anthropological institute was established in 1881. Zoologist Professor Méhely Lajos (1862-1953) with his appointment in 1920 slightly “misled” the Hungarian scientific approach to anthropology, which lasted until his retirement in 1930. The return to anthropological aspects of real habits was due to Bartucz Lajos, who dealt with truly scientific anthropology. Following the war, the status of the institute in Budapest and Szeged changed to department. In 1959 Bartucz was appointed to lead the Budapest Institute, which he led till his death in 1966. In the academic year 1990-91, with the leadership of Boglár Lajos three instructors separated from the Department of Ethnology of Eötvös Loránd University, and with the support of the Soros Foundation and of the Tempus program, cultural anthropology education was first launched in Hungary. Kunt Ernő founded the Cultural and Visual Anthropology Department in 1992 at the University of Miskolc. In 1995, after Kunt's death, the academic chair was been taken over by Borsányi László from Budapest. At the University of Pécs and its predecessor, the Janus Pannonius University regular training has been conducted since September 1991, which was launched in 1989 by Professor Andrásfalvy Bertalan.

\section{The action anthropology}

Action anthropology unfolded during the colonial period and was rejected by the anthropologist society, just as military anthropology, which surfaced in the $21^{\text {st }}$ century as a new trend. This scientific approach has been called "colonial anthropology” within anthropology. In Great Britain the army got in direct contact with trained social scientists during the colonial period. As a result of sudden development, anthropology was deeply linked to colonial politics. Already in 1908, anthropology courses started among the people of the Sudan Civil Service. This relationship was quickly institutionalized in 1921 when, the International African Institute was founded to learn more about foreign cultures and languages, its leader was the former governor of Nigeria.[1]

Bronislaw Malinowski - one of the most respected people in the history of anthropology — said that action anthropology is nothing more than a means to increase the efficiency of colonial policy. It is a fact, that the appearance of this new direction of applied anthropology resulted in a significant difference of opinion, with which governments lived during the blooming of the colonial period. Many anthropologists and government officials had the intention of using the methods of anthropology to help the development of a colonial square alignment of foreign cultural environment, but under the control of the west. Many anthro- 
pologists admitted to - those who took part in the work — really using their skills to serve the European expansion and dissemination of ideas. Many mention the name of RadcliffeBrown, a very well known researcher in anthropology, and debate the use of his skills and knowledge as the instrument of colonialism. He wrote his study at the University of Cape Town, which was designated to help to reduce the conflict between the white and the black population, and was used to strengthen the British colonial rule in individual colonies. The American Anthropologist Association, of course, disfavoured this level of anthropological support of governments, so it has repeatedly condemned those anthropologists who openly or covertly were involved in such activities So it happened that both Margaret Mead and Ruth Benedict also became the target of the organization, having done scientific research at the request of the U.S. government in World War II about Japanese culture. To date this is the best and most detailed work on Japanese society and Japanese social scientists acknowledge it. It deserves even more respect that all of this descriptive research was carried out without even having spent time in the country.

The status and importance of applied anthropology is acknowledged by the social scientists dealing with anthropology, despite the slight fear that can be felt from people engaged in this science nowadays. Of course, this science has no spotless history, as research carried out during the wars supported the political views of a given government to the detriment of the studied culture. This was the case with World War II, Vietnam, Burma, the Gulf War and today anthropologists are also employed in Iraq and Afghanistan.

\section{Action Anthropology in the Hungarian Armed Forces}

In the Hungarian Armed Forces, I look at three different levels and tasks of action anthropology:

1. At the operational level, in the planning phase;

2. Tactical levels, the appearance in the mission areas;

3. During the training for missions and in higher education.

The toolbar of cultural anthropology is best suited to design the obstacles ahead of us and prepare for expected events. In this case, the local cultural differences, local language recognition, building and exploring a network of contacts, tracing political units, these all can provide such information to the operational planning level that can make the evacuation and the start of workflow more efficient, economical and faster. Inclusion of first contact with the local population can only be executed by a qualified specialist, but a time of keeping in touch is also helpful when an already known specialist negotiates in a foreign country with foreign leaders. On a tactical level, the military anthropologist has to appear on the spot, operate locally with the military units and continuously collect information about the state between the military and the civilian sector, and communicate with local leaders and the local population. Without this knowledge, the relocation and work of military units is more dangerous, more expensive and takes more time. Thanks to a social scientist's research, more detailed and multidirectional information can be collected about the culture and the troops are more sensitive to changes. The disclosed information will not only be used for command and reconnaissance elements, but it can be integrated into the next shift's training, not to mention its role in military higher education, with which we will be able to train multi-dimensional thinking military leaders, who will be able to meet the challenges of the future. 
The building of this program requires no real huge extra cost, since neither a technical nor a developmental cost would be needed for the establishment of such a group, whether on campus or in one of the corps. The only cost is the application and recruitment of professionals who would apply their expertise to the task of national defence. More and more young anthropologists deal with the idea of military anthropology and the scientific and military potential in this science. However no step has been taken to create the ability for truly modern future military operations in the HDF. My previous articles have dealt with the American Human Terrain System's (HTS) work, but the British Defence Cultural Specialist Unit (DCSU) is also responsible for, among other things, social science methods assisting in military operations. [2]

In the U.S. national and international policy, it is not surprising that U.S. intelligence agencies are the main funders of the various secret social science projects in the world. [3] The United States and Great Britain launched two programs, which examined the possibility of social science application; these were the Intelligence Scholars Program and the Combating Terrorism Countering Radicalisation program. In the United States since April 2004, many intelligence agency analyst staff had to re-enroll in American universities to expand their expertise and knowledge of cultural anthropological knowledge, which has become necessary to carry out their work more accurately. In July 2006, the British Foreign and Commonwealth Office (FCO) and the Economic and Social Research Council (ESRC) jointly launched a 1.3 million pound initiative aimed at analyzing the extremist Islamic groups in five countries and six regions . The program's aim was to better understand the operation of terrorist groups and to develop an effective action against them. The fact is that the research program was not openly advertised, but MI5's Joint Terrorism Analysis Centre was involved in the planning. [4] The behaviour of smaller or larger communities can help or deeply impede military efforts. The understanding of local people's responses and their effects on our military operations are the keys for success. [5]

In Hungary, at several scientific conferences since 2007 (National University of Public Service, and University of Miskolc) examined the potential and indispensability of cultural anthropology in military exercises. NATO and the EU have continuously engaged in how this kind of methodology could effectively be applied in military planning and exercises, which is the most important tool of anthropology. Now only the opinion of the Hungarian Defence Forces is missing as to how this capacity could be built in and applied to the task force system.

\section{References}

[1] O’DRISCOLL, E.: Applying the Uncomfortable Science: the Role of Anthropology in Development. Durham Anthropology Journal, 161 (2009) 13-21.

[2] SZTANKAI K.: A kulturális antropológia alkalmazása az ISAF misszióban. Honvédségi Szemle, 1402 (2012), 36-38.

[3] SOLOVEY, M.: Project Camelot and the 1960's Epistemological Revolution: Rethinking the Politics-Patronage-Social Science Nexus. Social Studies of Science, 312 (2001), 171-206. DOI: https://doi.org/10.1177/0306312701031002003

[4] HOUTMAN, G.: Double or quits. Anthropology Today, 226 (2006), 1-3. DOI: https:// doi.org/10.1111/j.1467-8322.2006.00468.x

[5] BOLDIZSÁR G.: Military decision making and the human terrain. http://beachvolleyball. guidedbees.com/ ruben/EDSI/papers/boldizs\%E1r_military.pdf (downloaded: 2901 2014)

[6] ORTUTAY Gy. (Ed.): Magyar Néprajzi Lexikon. Budapest: Akadémiai Kiadó, 1977. (I. kötet) 